\title{
Crimean-Congo Hemorrhagic Fever infection in domestic animals in Marmara region, Western Turkey
}

\author{
Pelin TUNCER ${ }^{1}$, Kadir YESILBAG ${ }^{1}$, Gizem ALPAY ${ }^{1}$, Ender DINCER ${ }^{2}$, A. Onur GIRISGIN ${ }^{3}$, \\ Levent AYDIN ${ }^{3}$, Yavuz UYAR ${ }^{4}$, Aykut OZKUL ${ }^{2}$
}

\begin{abstract}
${ }^{1}$ Department of Virology, Uludag University Faculty of Veterinary Medicine, Bursa; ${ }^{2}$ Department of Virology, Ankara University Faculty of Veterinary Medicine, Ankara; ${ }^{3}$ Department of Parasitology, Uludag University Faculty of Veterinary Medicine, Bursa; ${ }^{4}$ Virology Laboratory, Refik Saydam National Public Health Agency (RSNPHA), Ankara, Turkey.
\end{abstract}

\begin{abstract}
Summary: Crimean-Congo hemorrhagic fever (CCHF) has been an important health issue in Turkey since the last decade. Although there is a well-described endemic area, the infection tends to disseminate into non-endemic areas. In the South Marmara region, a non-endemic area, serological and virological investigations were performed to evaluate the infection status in livestock animals. Among 508 blood samples collected from 5 different locations, 33.1\% were positive for CCHF-neutralizing antibodies. The highest seroprevalence rate was detected in goats $(66.0 \%)$, followed by sheep $(31.8 \%)$ and cattle $(13.0 \%)(\mathrm{p}<0.0001)$. There were extensive differences in seroprevalence rates in neighboring locations, i.e., 7.8\% in Keles and 47.6\% in the Orhaneli district of Bursa province. Using antigen-capture ELISA (Ag-ELISA) and real-time reverse transcription PCR (rt RT-PCR), 6.6\% of the tested animals were found to be viremic at the time of sampling. Two samples that were negative by Ag-ELISA produced a positive signal in rt RT-PCR, indicating the higher sensitivity of the latter method for detecting viremic animals. The results of this study demonstrate the wide distribution of CCHF virus in some locations in a non-endemic area, which may lead to the generation of focal infectious areas.
\end{abstract}

Key words: Cattle, Crimean-Congo hemorrhagic fever, ELISA, real-time RT-PCR, sheep, Turkey.

\section{Marmara bölgesindeki evcil hayvanlarda Kırım-Kongo Kanamalı Ateşi enfeksiyonu}

Özet: Kırım-Kongo kanamalı ateşi (KKKA) son on yıllık süreç içerisinde Türkiye'de oldukça önemli bir sağlık problemi olarak gündemde yer almaktadır. Endemik bölge olarak tanımlanan alanlar dışında kalan non-endemik bölgelerde de enfeksiyonun yayılma eğiliminde olduğu görülmektedir. Bu çalışmada non-endemik bölge olarak tanımlanan Güney Marmara bölgesindeki çiftlik hayvanlarında enfeksiyon durumunu değerlendirebilmek amacıyla serolojik ve virolojik araştırmalar yapılmıştır. Bu amaçla 5 farklı noktadan 508 adet kan örneği toplanmıştır. Bu örneklerin \%33,1’i KKKA-nötralizan antikorları yönünden pozitif çıkmıştır. En yüksek seroprevalans değeri keçilerde $(\% 66,0)$ saptanırken, bu değeri sırasıyla koyunlar $(\% 31,8)$ ve sığırlar $(\% 13,0)$ izlemiştir $(\mathrm{p}<0,0001)$. Seroprevalans değerlerinde komşu bölgeler arasında büyük farklar olduğu görülmüştür. Örneğin; Keles’te \% $\%, 8$ olan seroprevalans değeri Orhaneli'de \%47,6 olarak tespit edilmiştir. Antijen ELISA (Ag-ELISA) ve real-time reverse transkriptaz PCR (rt RT-PCR) kullanılarak test edilen hayvanların \%6,6'sının örnekleme sırasında viremi fazında olduğu tespit edilmiştir. Ag-ELISA ile negatif, rt RT-PCR ile pozitif sonuç veren iki örnek, ikinci metodun viremi fazındaki hayvanları saptamada daha duyarlı olduğunu göstermiştir. Bu çalışmanın sonucu KKKA virusunun non-endemik bölgenin bazı noktalarında oldukça yaygın olduğunu ve bu noktaların enfeksiyon odağı olabileceğini göstermiştir.

Anahtar kelimeler: ELISA, Kırım-Kongo kanamalı ateşi, koyun, real-time RT-PCR, Sığır, Türkiye.

\section{Introduction}

Crimean-Congo hemorrhagic fever (CCHF) is an acute zoonotic infection caused by the CCHF virus, a member of the genus Nairovirus of the family Bunyaviridae. Serological investigations revealed that numerous wild and domestic vertebrates, including cattle, sheep and goats, are susceptible to the CCHF virus (19). Although high fever, malaise, severe headache, gastrointestinal symptoms, hemorrhage and a fatality rate of $5-50 \%$ are observed in infected humans, the virus generally produces no disease conditions in animal hosts. Animal species developing transient viremia and an antibody response to the CCHF virus are believed to serve as amplifying hosts for the agent. The virus is transmitted to humans mainly through the bite of an infected tick or by direct contact with the blood and tissues of infected animals or human patients (19).

The virus follows tick-vertebrate-tick cycles in nature. Because transovarial, transstadial and vertical transmission of the CCHF virus in ticks is possible (19), 
ticks are classified as not only the vector but also a reservoir for the virus (5). Hyalomma ticks, particularly $H$. marginatum, are accepted as the main vector for the CCHF virus, although more than 30 tick species have been shown to be capable of transmitting the virus between vertebrate hosts $(13,19)$.

$\mathrm{CCHF}$ is endemic in some parts of Africa, Asia, the Middle East, and south-eastern Europe. Sporadic cases of CCHF have been reported from different parts of the world since the 1970s. Serological evidence for the presence of the infection in Turkey has long been reported (13), and the first clinical human cases were described in 2002 (WHO) (20). These first cases were from the middle Black Sea region of the country, which is endemic for the infection (16). Since 2003, an increasing number of human cases have been reported, with a fatality rate of approximately 5\% (Turkish Ministry of Health). In the last decade, human cases have been reported from non-endemic areas, including the Marmara region in the northwest of the country (2). Although a detailed tick survey and virus detection in vector tick species have recently been performed in the region (22), there are insufficient data on CCHF virus infection in animals in Turkey. Because seroepidemiological findings effectively contribute to the probable risk of human CCHF cases in non-endemic areas, in this study, we aimed to demonstrate the infection status of livestock in the South Marmara region of Turkey through serological and virological investigations.

\section{Materials and Methods}

Study Area: The study was carried out in five locations in the Southern Marmara region, which is located in the northwestern part of the country (Fig. 1). The region has a coastal zone on the Marmara Sea and the Aegean Sea. In general, the humidity in lower lands is high, ranging from $70-75 \%$, whilst in high plateaus areas with poor water sources are present. The annual rainfall in the studied provinces varies between $455 \mathrm{~mm}$ (Bilecik) and $701 \mathrm{~mm}$ (Bursa). The annual extreme temperatures during the last 30 years were $-18.8{ }^{\circ} \mathrm{C}$ (Balıkesir) and $43.8^{\circ} \mathrm{C}$ (Bursa). The altitude of the study area varied between $200 \mathrm{~m}$ (Balıkesir province,

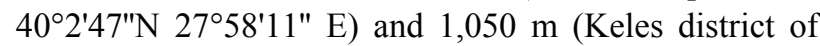
Bursa province, $\left.39^{\circ} 54^{\prime} 45^{\prime \prime} \mathrm{N} 29^{\circ} 11^{\prime} 44^{\prime \prime} \mathrm{E}\right)$.

Animals and Sampling: Field studies were performed during the spring and summer seasons of 2008 and 2009 in 5 locations of the South Marmara region, western Turkey. Blood samples used for serology, antigen detection and RNA isolation were collected from a total of 508 animals, including 201 cattle, 160 sheep and 147 goats (Table 1). All of the examined animals were over 1 year old and presented no clinical disorder at the sampling time. Blood samples were collected from the jugular vein by venipuncture. The sera were separated by centrifugation at $1,800 \mathrm{x}$ g, heat inactivated at $56^{\circ} \mathrm{C}$ for 30 minutes in order to inactivate indigenous complement, and frozen at $-80{ }^{\circ} \mathrm{C}$ until testing. Plasma obtained from non-clotted blood samples collected into EDTA-K 3 supplemented tubes was directly used for RNA isolation and antigen-capture ELISA.

Virus and Cell Line: The Vero E6 cell-adapted cytopatogenic CCHF virus strain Ank1/09 was used in the serological tests (10). Vero cells were grown in Dulbecco's modified minimal essential medium (DMEM) supplemented with $10 \%$ fetal calf sera.

Serological Examinations: Antibodies against the CCHF virus were detected using serum neutralization assay performed in BSL-3 facility of virology laboratory, Refik Saydam National Public Health Agency (RSNPHA). Serum samples were diluted 1:2 in DMEM and mixed with an equal volume of $100 \mu 1100 \mathrm{TCID}_{50}$ dilution of the virus strain Ank1/09 in duplicate. After 1 hour of incubation in a $5 \% \mathrm{CO}_{2}$ atmosphere at $37^{\circ} \mathrm{C}$, the serumvirus mixture was inoculated onto 1-day-old Vero E6 cell cultures prepared in 24-well plates. Infected plates were further incubated under the same conditions for 4 days before the virus-induced cytopathogenic effects were evaluated under an inverted light microscope. The complete inhibition of viral growth in the test wells was

Table 1. Seroprevalance of Crimean-Congo haemorrhagic fever virus among tested animal species.

Tablo 1. Test edilen hayvan türlerinde Kırım-Kongo kanamalı ateşi virusunun seroprevalansı.

\begin{tabular}{|c|c|c|c|c|c|c|c|c|c|}
\hline & \multirow{3}{*}{ Locations } & \multicolumn{8}{|c|}{ Antibody detection } \\
\hline & & \multicolumn{2}{|c|}{ Total* } & \multicolumn{2}{|c|}{ Cattle } & \multicolumn{2}{|c|}{ Sheep } & \multicolumn{2}{|c|}{ Goats } \\
\hline & & $\mathrm{n}$ & $\%$ & $\mathrm{n}$ & $\%$ & $\mathrm{n}$ & $\%$ & $\mathrm{n}$ & $\%$ \\
\hline 1 & Orhaneli-Bursa & 60 & 47.6 & 34 & 35.0 & 4 & 100.0 & 22 & 52.6 \\
\hline 2 & Keles-Bursa & 42 & 7.8 & 21 & 0.0 & 16 & 25.0 & 5 & 0.0 \\
\hline 3 & Bursa & 69 & 18.6 & 45 & 22.8 & 24 & 0.0 & - & - \\
\hline 4 & Balıkesir & 244 & 40.8 & 64 & 0.0 & 80 & 37.5 & 100 & 72.2 \\
\hline \multirow[t]{2}{*}{5} & Bilecik & 93 & 24.1 & 37 & 22.2 & 36 & 22.8 & 20 & 30.0 \\
\hline & TOTAL & 508 & 33.1 & 201 & 13.0 & 160 & 31.8 & 147 & 66.0 \\
\hline
\end{tabular}

\footnotetext{
* Some samples could not been tested due to insufficient volume or bacterial contamination
} $\mathrm{n}$ : Number of animals sampled 
evaluated as a positive result for CCHF virus antibodies. Serological results were statistically compared by Chisquare and Fisher's exact tests using Instat software.

Antigen-capture ELISA: CCHF antigens were detected using antigen-capture ELISA. Non-clotted blood samples were centrifuged at $1,800 \mathrm{x}$ g at $+4{ }^{\circ} \mathrm{C}$ for 10 minutes. The plasma fraction was collected and subjected to antigen-capture ELISA using a commercially available ELISA kit (Vecto Crimea-CHF-antigen, Vector Best, Russia) according to the manufacturer's protocol.

Real-time RT-PCR: Viral RNA was isolated from plasma samples using a viral nucleic acid extraction kit (High Pure, Roche Diagnostics GmbH, Germany). The protocol was applied as indicated in the user's manual. Viral RNA was dissolved in $30 \mu \mathrm{l}$ of elution buffer and subjected to real-time reverse transcription PCR (rt RTPCR) as previously described (21). The assay was performed with a Rotorgene 6000 (Corbett, Australia) thermo-cycler using a combination of Superscript III RT/Platinum Taq ${ }^{\circledR}$ Mix enzymes (Invitrogen, USA). The test conditions were as follows: $94^{\circ} \mathrm{C}$ for $10 \mathrm{~s} ; 50$ cycles of $94^{\circ} \mathrm{C}$ for $10 \mathrm{~s}, 60^{\circ} \mathrm{C}$ for $10 \mathrm{~s}$, and $72{ }^{\circ} \mathrm{C}$ for $1 \mathrm{~min}$; and a final elongation at $75^{\circ} \mathrm{C}$ for $5 \mathrm{~min}$. Fluorescence detection was performed at the end of the annealing step in each cycle.

\section{Results}

Serological survey: Neutralizing antibodies against $\mathrm{CCHF}$ virus were detected in all of the screened locations and all 3 of the animal species tested (Table 1). On the regional basis, the highest antibody prevalence (47.6\%) was found in Orhaneli, and the lowest $(7.8 \%)$ was in the Keles district of Bursa province. There were significant differences among all of the locations, except between locations 1 and 4, 2 and 3, and 3 and 5. The average seroprevalence in tested animals was $33.1 \%$. The highest antibody prevalence $(66.0 \%)$ was detected in goats, followed by sheep (31.8\%) and cattle (13.0\%). The difference in seroprevalence values among the animal species was significant $(\mathrm{p}<0.0001)$.

Tablo 2. Test edilen hayvan türlerinde Antijen ELISA ve rt RT-PCR ile Kırım-Kongo kanamalı ateși virusu tespiti.

Table 2. Crimean-Congo haemorrhagic fever virus detection in tested animal species by antigen capture ELISA and rt RTPCR.

\begin{tabular}{lccc}
\hline & \multicolumn{3}{c}{ Number of CCHF virus (+) } \\
Location & $\begin{array}{c}\text { Animal } \\
\text { Species }\end{array}$ & $\begin{array}{c}\text { Ag ELISA } \\
(+)\end{array}$ & $\begin{array}{c}\text { Ag ELISA (-) } \\
\text { / rt RT-PCR (+) }\end{array}$ \\
\hline Bilecik & Cattle & 10 & \\
Orhaneli-Bursa & Goats & 8 & 1 \\
Keles-Bursa & Sheep & 1 & \\
Bursa & Sheep & 7 & \\
Balikesir & Sheep & 6 & \\
\hline & Total & & 34 \\
\hline
\end{tabular}

Ag ELISA: Antigen capture ELISA

rt RT-PCR: Reverse transcription real time polymerase chain reaction

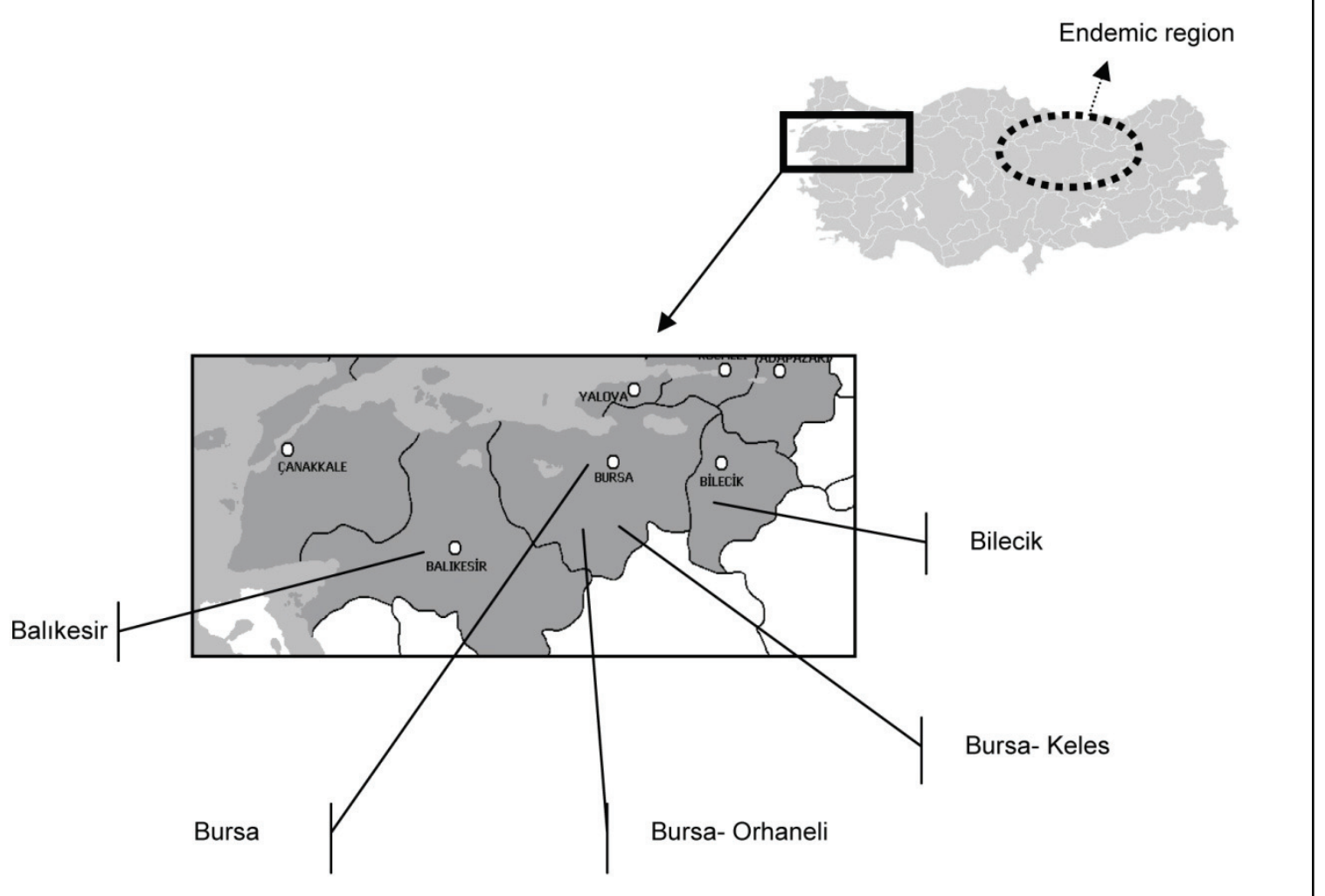

Figure 1. Studied locations of the South Marmara region in Turkey.

Şekil 1. Güney Marmara bölgesinde örnekleme çalışmalarının yürütüldüğü alanlar. 
Viral antigen and RNA detection: A total of 32 animal blood samples were positive for CCHF viral antigens using antigen-capture ELISA. These results were confirmed using rt RT-PCR. Using rt RT-PCR, 2 blood samples that had negative ELISA results were found to be positive for CCHF viral RNA (Table 2). Therefore, the rate of animals that were positive for CCHF virus was $6.6 \%$ (34:508). Regarding animal species, the highest rate of viremic animals was detected in sheep $(8.1 \%)$, followed by goats $(5,4 \%)$ and cattle (4.9\%). Differences among animal species were not statistically significant $(p>0.05)$. The presence of the CCHF virus was also demonstrated in tick species collected from infected cattle, sheep and goats (data not shown).

\section{Discussion and Conclusion}

Crimean-Congo hemorrhagic fever virus infections have been reported in many countries from the Middle East, Africa, Asia and Europe. During the last decade, the presence of infections due to the CCHF virus has also been demonstrated in endemic regions in Turkey $(8,16$, 23). The transmission of the infection into non-endemic areas of the country has been studied $(4,6)$. Incursion of the CCHF virus into the South Marmara region, a nonendemic area, was confirmed by existence of clinical human cases (2), and the presence of infection in tick species was demonstrated (22). There are insufficient data on animal infection with the CCHF virus in Turkey. Because the assessment of CCHF antibodies in livestock is one of the best indicators of CCHF risk for humans (3), the infection status of animals in the non-endemic area was investigated by serological and virological methods.

Serological studies conducted in a total of 508 sera revealed that $33.1 \%$ of the tested animals had been introduced to the infection. The highest seroprevalence rate was detected in goats $(66.0 \%)$, followed by $31.8 \%$ and $13.0 \%$ in sheep and cattle, respectively. Statistically significant differences among the three ruminant species could be related to the susceptibility of animal species and the distribution of vector ticks. One possible reason for the lower prevalence of infection in cattle (13.0\%) could be the low frequency of pasture usage of dairy cattle in the region; however, small ruminants are continuously in the pasture during the season. In accordance with our results, similar studies $(7,12,14$, $15,18)$ confirmed that the CCHF antibody prevalence is generally higher in small ruminants than cattle. Although there are no similar data from Turkey to compare the results, very limited surveys were conducted in the endemic region. Reported seroprevalence of CCHF virus was $17 \%$ in cattle and $37 \%$ in sheep (9), and a high rate (79\%) was reported in another study in cattle (17).
Recently, Albayrak et al (1) reported an antibody prevalence of $66 \%$ in sheep and $85 \%$ in goats. Taken together, our results show that CCHF may have different epidemiological patterns in animals in endemic and nonendemic regions.

Different serological results have been reported in livestock animals in various countries, i.e., $57.7 \%$ in Niger (11), 39.3\% in Iran (15), and 3.13\% in Egypt (12). The overall seroprevalence rate of $33.1 \%$, which is comparable to some previous studies (18), indicates that $\mathrm{CCHF}$ virus infection is moderately distributed throughout the studied population. The existence of extremely different infection rates among provinces in the same country was previously reported in Iran (3). In the present study, the highest $(47.6 \%)$ and the lowest (7.8\%) prevalence rates were observed in Keles and Orhaneli districts of Bursa province, which are closely neighboring towns. This situation may indicate the enormous effect of microclimate on the epidemiology of CCHF.

Using antigen-capture ELISA, 32 out of 508 animal blood samples were found to be positive for CCHFV antigens. An additional 2 samples were found to be positive by rt RT-PCR, indicating the superior sensitivity of this method to identify viremic animals. In our recent studies, the presence of the CCHF virus in 4 tick species (Rhipicephalus turanicus, R. bursa, H. marginatum, and D. marginatus) and $12.3 \%$ of the tested tick pools from the region was demonstrated (22). Taken together, the identification of $6.6 \%(34: 508)$ of the tested animals as viremic suggests the active circulation of the virus in the South Marmara region, which is accepted as a nonendemic area. Despite this circulation, the low incidence of human cases in the region may be due to unidentified rural cases without death. Another possible reason is narrow infection foci in high-altitude locations, leading to minimum contact with city life, including a highdensity human population.

In conclusion, the results of the present study that evaluated the seroprevalence rates of the CCHF virus in ruminant species in the South Marmara region of Turkey demonstrate that Crimean-Congo hemorrhagic fever infection can be widespread among sheep and goats in infected foci, even those located in non-endemic areas. Higher seroprevalence rates and viremia detected in livestock may lead to future endemicity in rural areas. Similar studies in other non-endemic areas and wild animals may be helpful to create an epidemiological risk map.

\section{Acknowledgments}

This work was supported by the Research Fund of the University of Uludag, Project no: V-2007/31. 


\section{References}

1. Albayrak H, Ozan E, Kurt M (2012): Serosurvey and molecular detection of Crimean-Congo hemorrhagic fever virus (CCHFV) in northern Turkey. Trop Anim Health Prod, 44, 1667-1671.

2. Boluk G, Ozvatan-Şener T, Yılmaz E, Akalın H, Mıstık R, Helvacı S (2009): Crimean-Congo Haemorrhagic Fever in South Marmara Region, Turkey. Klimik, 22, 100102.

3. Chinikar S, Ghiasi SM, Hewson R, Moradi M, Haeri A (2010): Crimean-Congo hemorrhagic fever in Iran and neighbouring countries. J Clin Virol, 47, 110-114.

4. Ertugrul B, Uyar Y, Yavas K, Turan C, Oncu S, Saylak O, Carhan A, Ozturk B, Erol N (2009): An outbreak of Crimian-Congo hemorrhagic fever in western Anatolia, Turkey. Int J Infect Dis, 13, 431-436.

5. Faye O, Cornet JP, Camicas JL, Fontenille D, Gonzalez JP (1999) : Experimental transmission of Crimean-Congo hemorrhagic fever virus: role of 3 vector species in the maintenance and transmission cycles in Senegal. Parasite, 6, 27-32.

6. Hekimoglu O, Ozer N, Ergunay K, Ozkul A (2012): Species distribution and detection of Crimean Congo Hemorrhagic Fever Virus (CCHFV) in field-collected ticks in Ankara Province, Central Anatolia, Turkey. Exp Appl Acarol, 56, 75-84.

7. Hassanein KM, el-Azazy OM, Yousef HM (1997): Detection of Crimean-Congo haemorrhagic fever virus antibodies in humans and imported livestock in Saudi Arabia. Trans R Soc Trop Med Hyg, 91, 536-537.

8. Karti SS, Odabasi Z, Korten V, Yilmaz M, Sonmez M, Caylan R, Akdogan E, Eren N, Koksal I, Ovali E, Erickson BR, Vincent MJ, Nichol ST, Comer JA, Rollin PE, Ksiazek TG (2004): Crimean-Congo hemorrhagic fever in Turkey. Emerg Inf Dis, 10, 1379-1384.

9. Kirbas A, Ozdemir H, Aksözek A (2010): The investigation of Crimean-Congo Haemorrhagic fever virus infection seroprevalance in cattle and sheep in Elaziğ, Samsun, Sivas, Tokat and Yozgat provinces. Firat Univ J Health Sci, 24, 137-142.

10. Kubar A, Haciomeroglu M, Ozkul A, Bagriacik U, Akinci E, Sener K, Bodur H (2011): Prompt administration of Crimean-Congo hemorrhagic fever (CCHF) virus hyperimmunoglobulin in patients diagnosed with CCHF and viral load monitorization by reverse transcriptase-PCR. Jpn J Infect Dis, 64, 439-443.

11. Mariner JC, Morrill J, Ksiazek TG (1995): Antibodies to hemorrhagic fever viruses in domestic livestock in Niger: Rift Valley fever and Crimean-Congo hemorrhagic fever. Am J Trop Med Hyg, 53, 217-221.

12. Mohamed M, Said A, Murad A, Graham R (2008): $A$ serological survey of Crimean-Congo haemorrhagic fever in animals in the Sharkia governorate of Egypt. Vet Italiana, 44, 513-517.
13. Swanopoel R (1994): Crimian-Congo hemorrhagic fever. 149-161. In: Beran GW (Ed), Handbook of Zoonoses, section B: Viral. $2^{\text {nd }}$ ed. CRC Press, New York.

14. Tantawi HH, Shony MO, Al-Tikriti SK (1981): Antibodies to Crimean-Congo haemorrhagic fever virus in domestic animals in Iraq: a seroepidemiological survey. Int J Zoonoses, 8, 115-20.

15. Telmadarraiy Z, Ghiasi SM, Moradi M, Vatandoost $\mathbf{H}$, Eshraghian MR, Faghihi F, Zarei Z, Haeri A, Chinikar S (2009): A survey of Crimean-Congo haemorrhagic fever in livestock and ticks in Ardabil Province, Iran during 2004-2005. Scand J Infect Dis, 42, 137-141.

16. Tonbak S, Atas M, Altay K, Azkur AK, Kalkan A, Bolat Y, Dumanli N, Ozdarendeli A (2006): CrimianCongo hemorrhagic fever virus: Genetic analysis and tick survey in Turkey. J Clin Microbiol, 44, 4120-4124.

17. Vatansever Z, Uzun R, Estrada-Pena A, Ergonul O (2007): CCHF in Turkey. 59-74. In: Ergonul $\mathrm{O}$ and Whitehouse CA. (Eds.), Crimean-Congo Hemorrhagic Fever-a global perspective. Springer, Dordrecht, The Netherlands.

18. Williams RJ, Al-Busaidy S, Mehta FR, Maupin GO, Wagoner KD, Al-Awaidy S, Suleiman AJ, Khan AS, Peters CJ, Ksiazek TG (2000): Crimean-Congo haemorrhagic fever: a seroepidemiological and tick survey in the Sultanate of Oman. Trop Med Int Health, 5, 99-106.

19. Whitehouse CA (2004): Crimian-Congo hemorrhagic fever. Antivir Res, 64, 145-160.

20. WHO (World Health Organization Regional Office for Europe). Epidemiology for Crimian-Congo haemorragic fever virus: Turkey, Russian Federation, Bulgaria, Greece, Albania, Kosovo. Available at: www.euro.who.int/surveilence /outbreaks/ 20080806_1

21. Yapar M, Aydogan H, Pahsa A, Besirbellioglu BA, Bodur H, Basustaoglu AC, Guney C, Avci IY, Sener K, Setteh MH, Kubar A (2005): Rapid and quantitative detection of Crimean-Congo hemorrhagic fever virus by one-step real-time reverse transcriptase-PCR. Jpn J Infect Dis, 58, 358-62.

22. Yesilbag K, Aydin L, Dincer E, Alpay G, Giriskin O, Tuncer P, Özkul A (2013): Tick survey and detection of Crimean-Congo hemorrhagic fever virus in tick species from a non-endemic area, South Marmara Region, Turkey. Exp Appl Acarol, 60, 253-261.

23. Yılmaz GR, Buzgan T, Irmak H, Safran A, Uzun R, Cevik MA, Torunoglu MA (2009): The epidemiology of Crimean-Congo hemorrhagic fever in Turkey, 2002-2007. Int J Infect Dis, 13, 380-386.

Geliş tarihi: 29.04.2013 / Kabul tarihi: 25.09.2013
Address for correspondence:
Prof. Dr.Kadir Yeşilbăg (DVM, PhD)
Uludag University, Faculty of Veterinary Medicine,
Department of Virology, Bursa-Turkey
e-mail:kyesilbag@uludag.edu.tr 